\title{
Supervision Improve the Professional Competence of Cultural Arts Teachers
}

\author{
Junita Ratnasari*, Cut Zahri Harun, Niswanto \\ Educational Administration Department \\ Syiah Kuala University \\ Banda Aceh, Indonesia \\ *junitamap310@gmail.com
}

\begin{abstract}
The research objectives were to determine the program, program implementation, and follow-up of the academic supervision program at SMPN 1 Peureulak. The research method used is descriptive qualitative. The results showed that the supervisor made the program to determine a schedule for the implementation of supervision at the beginning of each new academic year with a frequency of once per semester, indicating that it could improve the competence and performance of cultural arts teachers in planning and implementing meaningful and quality teaching and learning activities. The conclusion is that supervision by supervisors of teachers can create competent and professional teachers. This can be done by compiling a program one semester once, implementing the program that has been planned and communicating to teachers about the implementation of supervision, and following up on the implementation of supervision such as holding discussions with teachers regarding problems, obstacles faced in order to provide solutions or solving problems faced by teachers, including the problem of increasing the professional competence of teachers.
\end{abstract}

Keywords-professional competence, school supervisor and supervision

\section{INTRODUCTION}

Education as a strategic tool to improve people's lives. Through education, humans become intelligent, have skills, have good attitudes, and can help themselves. Schools are formal educational institutions that are expected to be able to improve the quality of education. Daryanto argues that: "Schools have a big responsibility for the development of students and improving the quality of education in schools by maximizing the use of school components in social life the real surroundings" [1].

The success of education in schools is very much determined by the teacher, because the teacher is the leader of learning, the facilitator, and at the same time is the center of learning initiatives that require teachers to develop selfcompetence according to the development of science and technology.

The competence of the arts and culture teacher, Alam states that: "In mastering the field of arts, it must be accompanied by the ability to understand the state of students, analyse and develop curriculum, plan art learning, conduct assessments and evaluations" [2]. Sukoco and Kunartinah states that: "The ability of teachers to manage the learning process is reflected in the quality of teachers in carrying out their duties and functions as educators and teachers, but in essence teachers are smart in practice but cannot teach or vice versa" [3].

The role of supervisory supervision is also felt to be effective in increasing the competence of teachers of arts and culture and can support the implementation of education in schools. A supervisor after compiling a supervision program is required to carry out academic supervision, namely a series of activities to help educators and education personnel develop their abilities to manage the learning process to achieve learning goals. Academic supervision is not for the assessment of the work of educators but to help educators develop their professional skills.

Teacher competence, Mulyati [4] is defined as the set of knowledge, abilities, and beliefs that a teacher has and is displayed for teaching situations. Meanwhile, teaching competency is defined as observable teacher behaviour. Competence is divided into 4 domains as confirmed by Law No. 14 of 2005 [5] on teachers and lecturers that competencies include: pedagogical competence, personality competence, social competence and professional competence obtained through professional education. The four teacher competencies in their implementation are actually an integral unit, and constitute an 'umbrella', because they cover all the competencies that a teacher must have [6].

Professional competency indicators consist of four indicators including mastering the educational foundation, mastering teaching materials, compiling teaching programs, implementing teaching programs, and assessing the results and teaching and learning processes that have been implemented. [7]. The characteristics of professionally competent teachers were conveyed by Gary and Margaret, namely having the ability to create a conducive learning climate, being able to develop learning strategies and management, being able to provide feedback and reinforcement, and being able to improve themselves [8]. 
The indicators of teacher professional competence are broader in scope, ranging from the ability to master all aspects of classroom learning to the ability to improve themselves to become professionally competent teachers.

Based on the background of the problem that the author has described, the researcher feels the need to conduct a study entitled increasing the professional competence of cultural arts teachers through supervision by supervisors at SMP Negeri 1 Peureulak, East Aceh Regency.

\section{RESEARCH METHODS}

The method used in this research is qualitative. namely a research method that describes and describes systematically, factually, and accurately regarding subjects and objects, facts and relationships between the phenomena being investigated, especially those related to the implementation of supervision by supervisors to improve the professional competence of cultural arts teachers at SMP Negeri 1 Peurelak East Aceh District.

\section{RESULTS AND DISCUSSION}

\section{A. Academic Supervision Program by School Supervisors}

From the results of the interview analysis at SMPN 1 Peureulak, it was confirmed that the supervisor made plans, programs and implementation of supervision that had been agreed upon with the teacher. Supervision activities begin with careful supervision planning. In order for supervision to be carried out properly, the principal must first make a plan and program of supervision. This finding is supported by previous researchers conducted by Maralih [9], Selvia [10], and Safrida [11].

The academic supervision program is arranged twice a year at the beginning of the new academic year, namely the annual and semester programs. The annual program is prepared for the district level by several supervisors who are specially assigned by the supervisory coordinator in accordance with their authority. The annual program is a reference for supervisors at SMPN 1 Peureulak to compile a semester program. The supervisory semester program is prepared by each principal and staff before the person concerned carries out supervision. This program contains the school supervision schedule for SMPN 1 Peureulak which is his responsibility.

The first step is compiling a program at SMPN 1 Peureulak by determining a supervision schedule for teachers which is outlined again in the form of a program supervision work plan as well as arranging who will supervise. The planning of the academic supervision program by supervisors at SMPN 1 Peureulak is carried out in several stages with the aim of helping the principal carry out supervision of teacher performance, namely: (1) coordinating together with the deputy principal, senior teachers to form an academic supervision assistant team; (2) Formulating an academic supervision program, namely coordinating with the vice principal and senior teachers to form an academic supervision assistant team by issuing a principal's decree (SK). The team was formed to assist supervisors in carrying out their supervisory duties with the aim of streamlining academic supervision activities in school. Team members are based on higher ranks so that they can rate teachers who have lower ranks. This finding is supported by previous researchers conducted by Zega [12]. The purpose of developing a supervision program is a new and appropriate implementation of supervision activities to improve teacher competence and performance in planning and implementing quality teaching and learning activities.

The activity of formulating an academic supervision program at SMP Negeri 1 consists of formulating goals and targets to be achieved, a schedule of supervision and instruments that will be used in carrying out academic supervision. Academic Supervision at SMPN 1 Peureulak is carried out with the aim of: (1) Collecting objective, accurate and valid information regarding the implementation of the program, which includes: (a) Compilation of learning programs; (b) Implementation of learning; (c) Implementation of learning supervision; (d) Follow-up learning outcomes; (e) Identification of the level of achievement of the learning program according to the SNP; (2) Obstacles, weaknesses and program implementation are identified; (3) Formulation of a follow-up program on the results of school supervision to follow up on existing problems.

This process is a step for supervisors to formulate and determine activities or steps that will be achieved in order to achieve effective and efficient goals [1]. This is in accordance with the research results of Sariyah which states that: "In planning academic supervision activities are carried out by means of small meetings with senior teachers then formulating a supervision program to be implemented" [13]. According to Sahertian [14], Understanding that planning in planning has; (1) The goals to be achieved and concretely clear; (2) Problems arising from members arising from important questions and according to needs; (3) personal matters with meeting matters needing attention; (4) new experiences obtained by his servant teachers can lead to better personal growth; (5) The participation of teachers from planning to implementation is considered; (6) problems with local conditions and time and place are taken into consideration in planning.

Based on the research results, supervision has been carried out by planning, implementing, monitoring and following up in accordance with the supervision guidelines and Teacher Performance Assessment (PKG) guidelines from the Ministry of National Education. Supervisors have made continuous efforts to improve the quality of academic supervision which aims to assist teachers in developing the learning process so that they can show changes in teacher performance in learning. The success of educational supervision can be measured by increasing academic and non-academic achievement. Education supervision plays a role in supervising the activities of the running of education, correcting deficiencies and errors in the education process, planning, observing, guiding and controlling to improve the quality of education in Indonesia. This finding is supported by previous researchers conducted by 
Agustina [15]. The academic supervision program at SMP Negeri 1 Peureulak has been implemented according to procedures both annually and semiannually with a frequency of supervision once per semester. The schedule prepared by the principal and senior teachers is affixed to the teacher magazine consisting of the day, date, month, hour, class, and supervisor.

\section{B. Implementation Academic Supervision by School Supervisors}

The implementation of supervision at SMP Negeri 1 Peureulak uses three stages of supervision procedures, namely: (1) the initial meeting stage; (a) The teacher is given a questionnaire containing various class administrations; (b) Reviewing administration/ responsibility assignments; (c) Conclusion of the agreement assessment on timing; (2) The stage of class visits and teaching observation: the teacher who is teaching is observed by the supervisor in accordance with the agreed corrective actions and timing; (3) The meeting stage after observation: (a) Provide reinforcement of opinion / feeling; (b) Review the problems in learning; (c) Review the completed questionnaire; (d) Providing guidance; (e) Determining follow-up.

Academic supervision at SMP Negeri 1 Peureulak is carried out twice in one semester using class visit and observation techniques through individual and group approaches. Supervision activities are carried out through various teaching problem solving processes. The aim is to increase the effectiveness and efficiency of the teachinglearning process. Supervision activities are carried out through various processes teaching problem solving. This finding is supported by previous researchers conducted by Selvia [10].

In improving the professionalism of teachers at SMP Negeri 1 Peureulak, the approach used by supervisors has actually been running as expected because supervisors have increased the frequency or time for the implementation of supervision, such as involving deputy principals or senior teachers, this is due to the large number of teachers who must be nurtured [12]. The implementation of academic supervision by supervisors in order to increase teacher professionalism is carried out by dividing academic supervision tasks with curriculum representatives to carry out supervision of senior teachers and senior teachers carrying out supervision of teachers in the field of study [16].

One of the implementation of school supervisor supervision is the implementation of academic supervision. There is a preobservation stage where in this pre-observation stage the supervisor and the supervisor team check the administration of teacher learning using prepared supervision instruments such as instructional administration starting from the educational calendar, annual programs, semester programs, calculation of effective weeks, learning syllabus, RPP, KKM, analysis evaluation items, and others.

The variety of problems and challenges faced by teachers. Supervisors use a variety of supervision techniques that are appropriate to the teaching problems experienced by educators
[17]. The supervision technique applied by supervisors at SMPN 1 Peureulak uses individual supervision techniques, namely class visits or class observations. The principal as a supervisor visits the class and conducts observations and interviews as well as document studies. Supervisors while conducting class visits fill out the instruments that have been prepared. From the instrument during the implementation of supervision, it is a document resulting from the supervision of teacher administration and the learning process. From the results of filling in these instruments, it can be seen how much the teacher's ability to prepare the learning administration and the learning process. Supervision is carried out through class visits to determine whether the class conditions are in accordance with the results of filling out the instruments. In addition, the principal observes the implementation of teaching and learning activities.

This class visit technique is often performed by supervisors as supervisors while doing activities to supervise teachers. The supervisor applies the principles and functions of class visits because the aim is to obtain data about the actual situation as long as the teacher is involved in the learning process in the classroom. With this objective data, supervisors as supervisors can provide guidance to teachers through discussions or private conversations about the results of supervision with classroom visit techniques so that efforts to improve and improve the quality of the skills and professionalism of cultural arts teachers at SMPN 1 Peureulak in the learning process can be achieved well. In other words, through classroom visit supervision techniques, objective data will be obtained regarding the difficulties of teachers in carrying out the learning process. Based on these difficulties, teachers will be helped to find solutions to problems faced by teachers.

Based on the results of observations at SMPN 1 Peureulak in the implementation of cultural arts teacher supervision, namely: Teacher 1 was supervised on Saturday, February 8, 2020 at 1 and 2 in class VIII-4 in the subject of cultural arts (music art) on the material of playing traditional music ensembles. The methods used are lectures, discussions and demonstrations, and a scientific approach. Teacher 1 had problems using learning media because he did not use video in explaining the material so that students found it difficult to understand the material. However, during the second supervision on March 4, 2020 in class IX-2 on art material (painting), there was progress from the implementation of the first supervision, namely the use of video when explaining the material. Teacher 2 was supervised on Thursday, February 13, 2020 at 1 and 2 in class VIII- 1 in the subject of cultural arts (music art) on the material of the traditional singing style. The methods used are lectures and demonstrations, discovery learning models, and scientific approaches.

Teacher 2 experienced problems in fostering student enthusiasm for the material on the style of singing traditional songs. There was progress during the second supervision on March 10, 2020 in class VIII-2 on dance art material (the uniqueness of traditional dance movements), which was able to foster student enthusiasm in PBM. 
Teacher 3 based on a predetermined schedule will be supervised on Monday March 22020 at 4 and 5 in class VII-1 in the subject of cultural arts (dance) on traditional dance accompaniment material. The methods used are lectures and demonstrations, and a scientific approach. Teacher 3 had a problem in class management so that students are less active in PBM. There was a change during the second supervision on March 17, 2020 in class IX-3 on music art material (modern songs in vocal group offerings), namely being able to manage the class so that PBM was more varied and fun. Teacher 4 based on a predetermined schedule will be supervised on Monday March 22020 at 1 and 2 in class VII-2 in the subject of cultural arts (fine arts) on illustration drawing material. The methods used are lectures, discovery learning models, and scientific approaches. Teacher 4 experienced problems in using technology during Covid-19 and could not meet face to face so that the material was not conveyed to students using the online method. At the time of the second supervision on March 28, 2020 in class VIII-3 on Fine Art material (drawing models) there had been progress from the implementation of the first supervision, namely being able to use technology in PBM with an online system.

Based on the results of observations at SMPN 1 Peureulak, it was illustrated that the conditions for the implementation of cultural arts teacher supervision were not good, meaning that teachers needed to improve the quality of the teaching and learning process. However, due to the covid-19 factor, supervisors experienced problems in including teachers in MGMP, workshops, training, seminars, and teacher meetings, in order to improve teacher problems in fostering student enthusiasm in arts and culture subjects, increasing the use of learning media, class management so that students are less active in PBM, the use of technology during Covid-19 and cannot face to face directly so that material is not conveyed to students using online methods.

Basically, an annual supervision program is prepared by the principal, wakakur and staff. The schedule that has been arranged is attached to the teacher's wall complete with the day, date, month and supervisor. In practice, there are still many teachers who are not supervised according to schedule. Based on the results of the interview, it was found that there were obstacles in the implementation of supervision because supervisors were often busy with unexpected agendas such as school principals' deliberation meetings (MKKS), visits by heads of offices, student competition meetings (FLS2N, OSN, FLSN), teacher race meetings, school assistance socialization meetings, and many others. However, this semester the biggest obstacle is covid-19.

\section{Follow-up Academic Supervision by School Supervisors}

The results of supervision need to be followed up so that they have a real impact on improving teacher professionalism. This real impact is expected to be felt by the community and stakeholders. The follow-up is in the form of reinforcement and rewards are given to teachers who have met standards, educational warnings are given to teachers who have not met the standards and teachers are given the opportunity to take part in further training / upgrading.

Based on the results of observations for the follow-up supervision of cultural arts teachers, it is necessary to make improvements to the learning process, namely teachers still need guidance in the learning process, classroom management, use of technology and use of learning media so that PBM is of higher quality and students have no difficulty in PBM. The follow-up form that the school supervisor does is in the form of sharing and questions and answers then the supervisor will listen to the teacher's explanation.

The results of the supervision carried out at SMPN 1 Peureulak have resulted in the following: (a) Most teachers have been able to create and organize learning program administration; (b) There are still only a few teachers who need to be coached to understand and improve competence and the preparation of learning administration; (c) The learning process has shown conformity to the lesson plans that have been prepared, but it needs to be directed at the learning process according to K-13 which leads to children as learning subjects; (d) In the supervision activity, there is a need for specific guidance on assessment techniques. This needs to be directed at a variety of instruments and assessment models.

After the supervisor announced the results of the supervision and the problem of the follow-up, the teacher responded positively and asked to be re-supervised. So the final follow-up of supervision is to note the points that are missing in the PBM then call the teacher and provide input from the shortcomings. So the teacher must see the results of supervision and what are the shortcomings. This activity is intended to identify and identify various difficulties and good or shortcomings of teachers during the learning process at school [10].

The empowerment of the teaching profession can be done through self-development that can carried out in a just, nondiscriminatory, democratic, and sustainable manner by upholding human rights, cultural values, religious values, professional code of ethics and national diversity. Academic supervision activities are one way that can be done in the program to empower teachers. Academic supervision is a series of process activities that help teachers develop or improve their ability to manage the learning process in order to achieve predetermined academic goals. The description of the professional competence of the cultural arts teacher at SMPN 1 Peureulak, seen from the aspect of his ability to master teaching materials, is very good, his ability to master $\mathrm{KI}$ and $\mathrm{KD}$ in fine arts, music and dance is very good, the ability to develop teaching materials is very good, the ability of class management is still lacking and it needs to be improved again, and the ability to develop teaching materials or learning media needs to be improved because the ability of the arts and culture teachers at SMPN 1 Peureulak in utilizing technology has different levels of ability. Some are good and some are not good. 
Teacher professionalism is in the high category if the four dimensions of teacher professionalism, namely improving and maintaining the professional image, pursuing professional quality and aspirations, pride in their profession, and professional development in improving the quality of teacher knowledge and skills have been fulfilled, it's just that in practice it is necessary improvement efforts, especially in the aspect of professional development in improving the quality of development and teacher skills.

Academic supervision of supervisors has a significant effect on teacher professionalism. This means that supervisors must further optimize guidance for teachers as a form of follow-up to the academic supervision program that they have made. Because supervision will be said to be meaningful if supervisors provide guidance to teachers in an effort to improve their professionalism, especially in improving the quality of teacher knowledge and skills which have an impact on improving the quality of education in schools. However, according to some teachers, there is still a lack of training to support professional competence.

Supervisors as academic supervisors in improving teacher professionalism should not only be armed with ability to plan programs and strategies for implementing academic supervision only, but must be able to follow up on the results of academic supervision in the form of coaching given to teachers who have been supervised, so that it is hoped that there will be positive changes in behavior as a result of coaching which will ultimately improve the quality of education. The results of supervision need to be followed up so that they have a real impact on improving teacher professionalism. This real impact is expected to be felt by the community and stakeholders. The follow-up is in the form of reinforcement and rewards are given to teachers who have met standards, educational warnings are given to teachers who have not met the standards and teachers are given the opportunity to take part in further training / upgrading [18].

This study shows that supervision has a direct influence on work motivation and education quality. The results of this study provide an understanding that supervision is an integrated part of the educational program in the form of cooperation and groups. Supervision that is carried out effectively affects one's professionalism [19]. In addition, the implementation of supervision has the aim of producing quality education in schools. Therefore, an effort to increase professionalism is to carry out programmed supervision, both in terms of planning, implementation and evaluation.

\section{CONCLUSION}

The supervisor has prepared a teacher supervision program involving the vice principal in the field of curriculum and senior teachers to supervise other teachers. The program prepared by the supervisor determines the schedule for the implementation of supervision at the beginning of each new academic year with a frequency of once per semester or one year or two. The purpose of developing a supervision program is to improve teacher competence and performance in planning and implementing meaningful and quality teaching and learning activities.

In the implementation stage of supervision, the supervisor makes a schedule with the teacher to be supervised, including in the monitoring planning stage. There is a pre-observation stage where the supervisor checks teacher learning administration uses the supervision instrument that has been prepared. Examinations are carried out to collect information or data where teachers experience problems in the implementation of learning, namely fostering student enthusiasm, class management so that students are less active in PBM, use of media, and use of technology during Covid-19 so that the material does not reach students.

The follow-up of supervision is to call teachers and provide input from their shortcomings, on professional competence in class management, the ability to develop teaching materials or learning media needs to be improved because the ability of cultural arts teachers at Peureulak 1 Middle School in utilizing technology has different levels of ability. Some are good and some are not good. The form of follow-up that school supervisors do is in the form of sharing and questions and answers, then the supervisor provides motivation to always improve teacher performance through education and training.

\section{REFERENCES}

[1] Daryanto, Evaluasi Pendidikan. Jakarta: Rineka Cipta, 2008.

[2] S. Alam, "Profesionalisme Guru Seni Budaya di Sekolah," Jurnal GETER Seni Drama, Tari dan Musik UNESA, vol. 2, no. 2, pp. 12-21, 2019.

[3] F. Sukoco dan Kunartinah, "Pengaruh Pendidikan dan Pelatihan, Pembelajaran Organisasi Terhadap Kinerja Dengan Kompetensi Sebagai Mediasi," Jurnal Bisnis dan Ekonomi (JBE), vol. 17, no. 1, 2010.

[4] Y.S. Mulyati, "Pengembangan Kompetensi Mengajar Guru Dalam Implementasi Manajemen Berbasis Sekolah," Jurnal Administrasi Pendidikan, vol. 23, no. 1, 2016 .

[5] Undang-undang Republik Indonesia. Nomor 14 Tahun 2005 tentang Guru dan Dosen. [Online]. Retrieved from: http://luk.staff.ugm.ac.id/atur/UU14-2005GuruDosen.pdf [Accessed on: 16 February 2020].

[6] S. Danim, Pengembangan Profesi Guru. Jakarta: Kencana Prenada Media Grup, 2011.

[7] M.U. Usman, Menjadi Guru Profesional. Bandung: PT Remadja Rosdakarya, 2011

[8] E. Mulyasa, Standar Kompetensi dan Sertifikasi Guru. Bandung: PT Remaja Rosdakarya, 2007

[9] Maralih, "Peranan Supervisi dalam Peningkatan Kualitas Pendidikan," Qathruna, vol. 1, no. 1, pp. 179-192, 2014

[10] Selvia, "Implementasi Supervisi Akademik Kepala Sekolah Dalam Peningkatan Profesionalisme Guru," Jurnal Manjer pendidikan, vol. 5, no. 1, pp. 43-49, 2015.

[11] Safrida, Pelaksanaan Supervisi Kepala Sekolah Dalam Meningkatkan Kompetensi Profesional Guru BK Pada SMAN 1 dan SMAN 2 Sigli. Electronic Thesis and Dissertations (ETD). Banda Aceh: Unsyiah, 2018.

[12] T. Zega, "Meningkatkan Kompetensi Profesional Guru Melalui Pelaksanaan Supervisi Akademik Oleh Kepala Sekolah Smp Negeri Lolowau Kabupaten Nias Selatan Tahun Pelajaran 2015/2016," Journal article Warta Dharmawangsa, no. 50, 2016. 
[13] Sariyah, Implementasi Supervisi oleh Kepala Sekolah (studi deskriptif kualitatif pada SDN 05 Bengkulu Selatan. Bengkulu: Tesis pada Prodi MAP FKIP PPs Universitas Bengkulu, 2013

[14] P.A. Sahertian, Konsep Dasar dan Teknik Supervisi. Jakarta: Penerbit Rineka Cipta, 2008.

[15] T. Agustina, "Peran Supervisi Pendidikan Dalam Meningkatkan Mutu Pendidikan di Indonesia," 2019. [Online]. Retrieved from: https://www.researchgate.net/publication/332922989_PERAN_SUPER VISI PENDIDIKAN DALAM MENINGKATKAN MUTU PENDID IKAN_DI_INDONESIA [Accessed on: 05 May 2020].
[16] A. Mardhiah, "Peningkatan Profesionalitas Guru Melalui Supervisi Akademik Di Smp Negeri 3 Peusangan Kabupaten Bireuen," Electrinic Theses and Dissertations (ETD), vol. 4, no. 2, pp. 1-11, 2014

[17] S. Sagala, Administrasi Pendidikan Kontemporer. Bandung: CV. Alfabeta, 2009

[18] E.A. Suwartini, "Supervisi Akademik Kepala Sekolah, profesionalisme Guru dan Mutu Pendidikan." Jurnal Administrasi Pendidikan, vol. XXIV, no. 2, 2017.

[19] Daryanti, "Pengaruh Supervisi dan Motivasi Kerja Terhadap Kualitas Pendidikan Sekolah Dasar Negeri di Kecamatan Makasar Jakarta Timur,” Jurnal Manajemen Pendidikan, vol. 4, no. 1, pp. 628-637, 2013. 